\title{
THE JOYS OF URBAN BIRDING: REGINA'S A. E. WILSON PARK
}

H. D. (SANDY) AYER, 1278 Campbell St., Regina, SK S4T 5P7, hdayer@cbccts.sk.ca

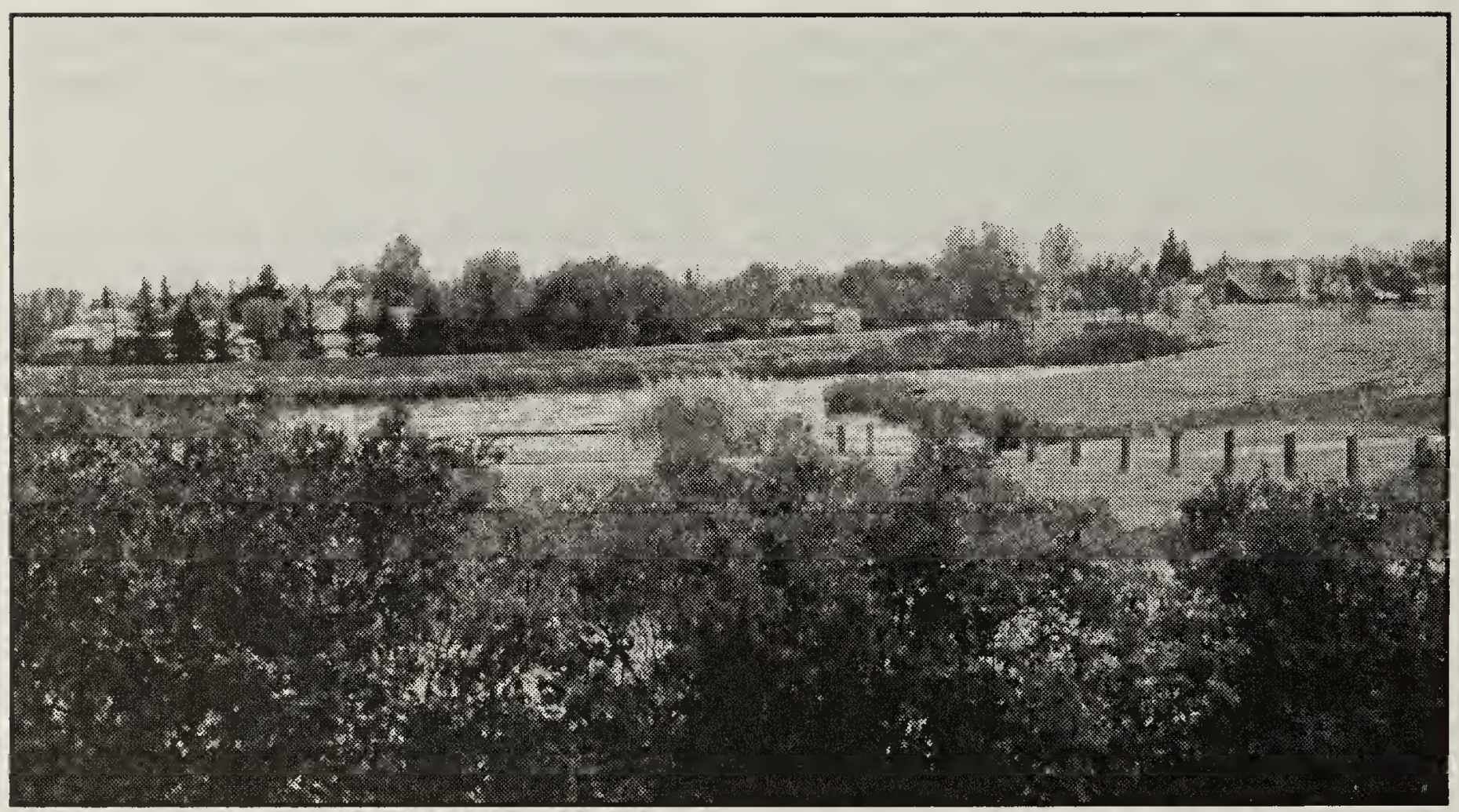

Figure 1. Looking across the s.e. end of A.E. Wilson Park, from the author's back yard.

Eric Greenway

I am a birder because of $A$. E. Wilson Park. It all started in the summer of 1985, our second in Regina. One afternoon, as I was walking along the south bank of Wascana Creek, I was captivated by a small flock of terns diving bill-first into the water only a few metres away. A few days later I caught sight of an American Bittern, posing stock-still with neck stretched skyward (like a photo out of National Geographic), among the reeds by the southernmost storm sewer outfall. Here I was, uprooted from beautiful, mountainous, forested British Columbia, transplanted into the midst of the apparently desolate prairie - and the place was teeming with birds! birds I'd never been aware of in my native province. (I later learned that Saskatchewan "boasts with the other two Prairie Provinces of having
Canada's richest assemblage of breeding birds"3). The magic of those early days - when every second bird was a life bird - has dissipated somewhat, but the joy of seeing some new aspect of bird behavior, and the thrill of adding new species to my checklist for the park, remain.

The park, which is situated in northwestern Regina, was officially dedicated in June, 1987. ${ }^{2}$ It is named after A. E. (Albert Edward) "Bert" Wilson (1908-1969), a Regina alderman who was a staunch advocate of parks and a supporter of Regina's northwest. Covering 80 hectares, it extends along both sides of Wascana Creek from Dewdney Avenue in the southeast to Ritter Avenue in the northwest (Fig. 2). As the largest park administered by the City of Regina (Wascana Park, which 
is larger, is administered by the Wascana Centre Authority), it is regarded by the city's Parks Department as something of a showcase for its multi-use philosophy of parks management. Indeed, the park includes not only a variety of wildlife habitats, but also tennis courts, a soccer pitch, two playgrounds, a canoelaunching dock, sewage pumping stations, and a heavily-used $4 \mathrm{~km}$ stretch of Regina's pathway/bikeway system. A master plan, adopted by city council in 1989, includes a number of elements that have not been implemented because of lack of funds. Among these is a complex including shops, markets, restaurants, and boat rental that was to have been built on a site adjacent to Rick Hansen Park (a playground on the north side of the park).

As far as wildlife habitat is concerned, the park contains a variety of human-made mini-environments, two of which were designed expressly to celebrate the diversity of Saskatchewan's ecosystems. Boreal Island, with its plantings of larch, spruce, and chunks of bog from Prince Albert, is intended to replicate the boreal forest, while Prairie Island just to the south, when fully developed, will become a microcosm of prairie grassland. The two islands, along with the hills along the east side of the park, were created between 1977 and 1980 by dredging and widening the creek. The original channel runs along the south side of both islands. The widening of the creek also served to increase its capacity to absorb spring runoff and the ever-increasing outflow from storm sewers in the rapidly developing nearby subdivisions. Weirs at each end of the park stabilize the water level during dry periods.

The sincerity of the Parks Department in seeking to make A. E. Wilson Park hospitable to birds and other wildlife can be seen from its decision to naturalize certain areas of the park. Large areas of grassland are left unmowed in summer to provide habitat for Western Meadowlarks and other grassland species. Unfortunately, this well-intentioned policy has backfired to

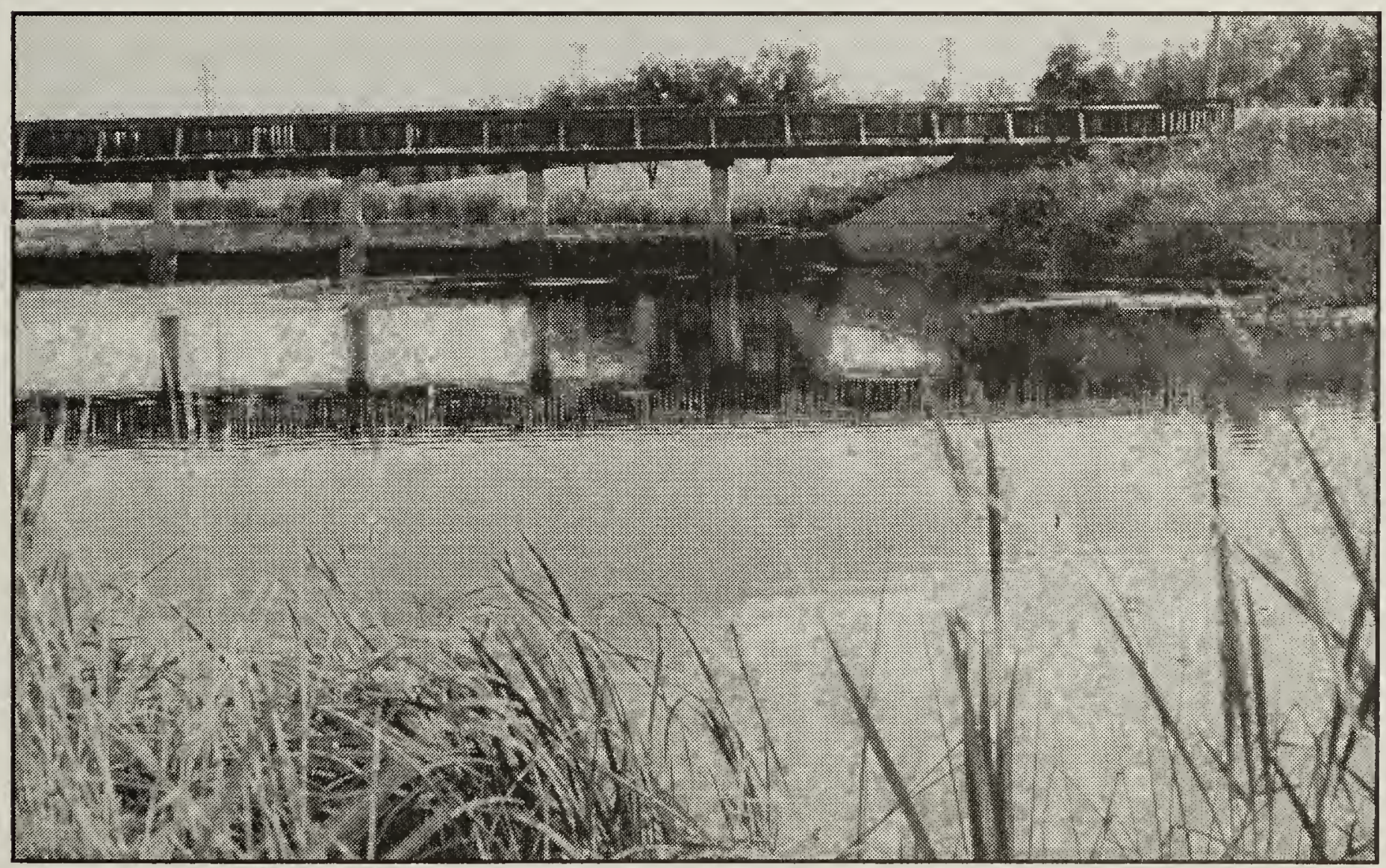




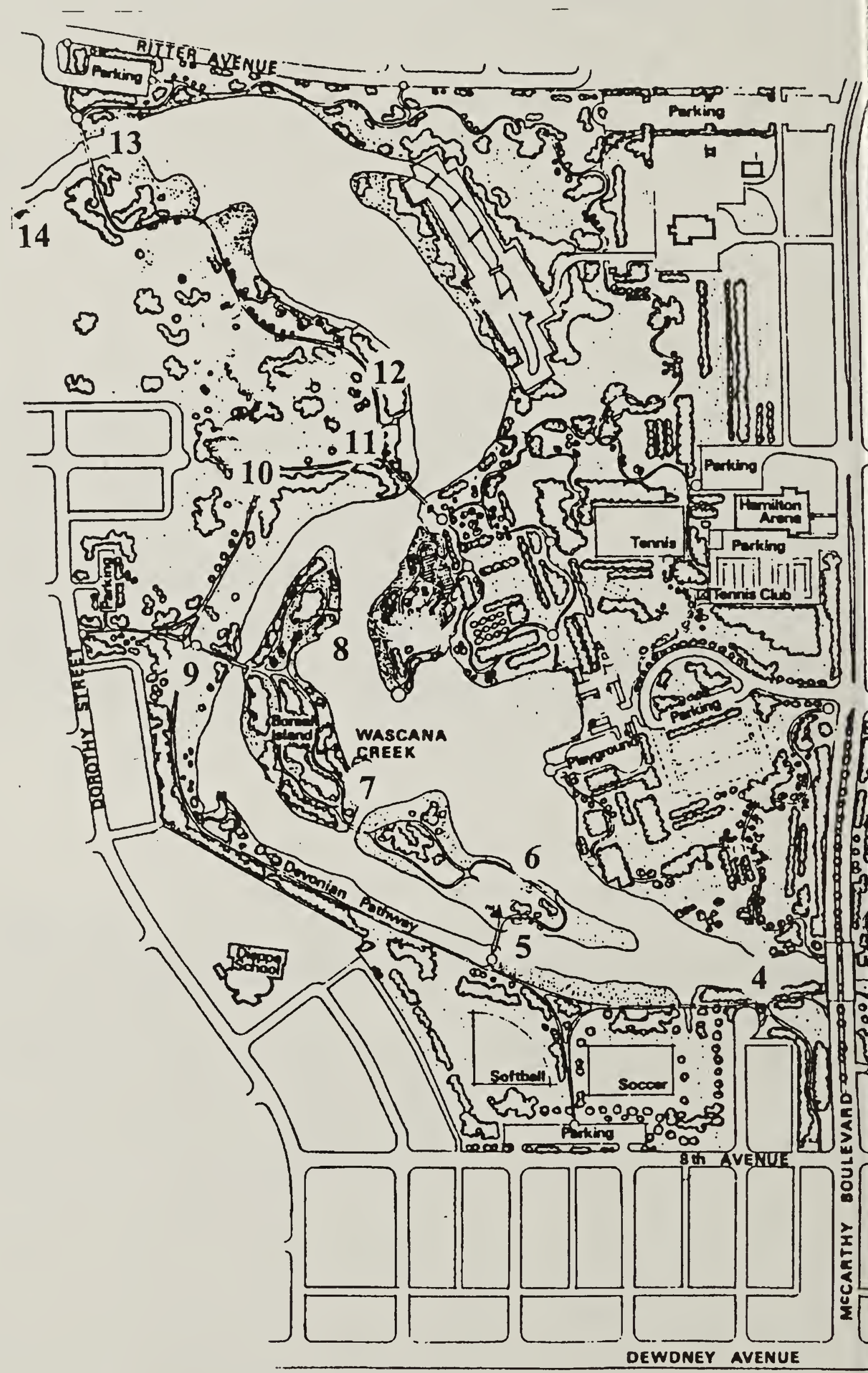


a certain extent since it allows weeds such as knapweed, clover, dock, burdock, and thistle to proliferate. Knapweed has already become a serious pest, having taken over significant chunks of former grassland. On a more ominous note, purple loosestrife, the hardy and prolific garden plant that has taken over numerous marshes in the western and eastern parts of the continent, has begun to turn up on Boreal Island. Fortunately, the parks maintenance department has so far managed to keep this scourge in check, but its presence is a reminder of the fragility of this riparian jewel of a park.

There are many places adjacent to the park where you can simply park your vehicle and walk in. However, I usually begin my birding forays at the $7^{\text {th }}$ Avenue and Campbell Street entrance because it adjoins my house (map location 1). In fact, I like to regard A. E. Wilson Park as an extension of my back yard. At any rate, starting where I do allows me to bird most of the park in the early morning with the sun pretty well at my back. I start by heading down the paved path that extends from the foot of Campbell Street to a footbridge over a weir about 400 metres to the southwest (map location 2).

The bridge (Fig. 3 ) is a great place to stop for an extended look and listen, but I've had enough close calls with cyclists and in-line skaters that I make sure to stand well back from the asphalt "bike path" that rings the park. Western Meadowlarks are usually singing in the vicinity from early spring until late summer, as are Eastern Kingbirds. Loggerhead Shrikes may have nested in the elms just to the southeast in 1988. That summer I observed one in our back yard pecking at my two-yearold son's running shoes that we'd hung out to dry on our clothesline.
Loggerhead Shrikes still occasionally show up in May in the more westerly portions of the park.

Barn Swallows nest in the nearby culvert, and in the spring and summer they are joined by Tree Swallows and Purple Martins, both of which nest in nearby yards. Common Yellowthroats-they seem to sing "wot'sis "ere?" instead of the more usual and prosaic "witchity, witchity, witchity"-and Song Sparrows often inhabit the thick willows and reeds on the south shore, as do the ubiquitous Red-winged Blackbirds. This dense foliage often shelters several species of sparrows during migration. They respond readily to pishing, provided one is not squeamish about pishing in public.

In the summer of 1999 a Hooded Merganser spent a few days fishing about 50 metres downstream from the bridge. Red-breasted and Common mergansers have also shown up in almost the same spot on a couple of occasions in the early spring. The same stretch of water usually harbors the more common migrating ducks and grebes. During the summer, Mallards, Northern Shovelers, American Wigeon, Blue-winged Teal and their young predominate. American Avocets are regular in spring, and every couple of years in early August local residents get a real treat when a small flock of American White Pelicans touches down. The reeds along the shore have sheltered not only the American Bittern mentioned above, but also, on a couple of occasions, a Black-crowned Night-Heron. Soras can be heard whinnying or giving their incessant "doo-wick" call, and, in fall, Common Snipe sometimes flush from the shallows. This is also one of the best places in the park to see Rusty Blackbirds (in the fall). 
For a couple of years during the mid' 90 s, there was a small sandbar on the shore opposite the culvert. It attracted the expected Spotted Sandpipers (which apparently breed in the park) and Greater Yellowlegs as well as the far less common Lesser Yellowlegs and, in fall, the occasional Long-billed Dowitcher. Unfortunately, this sandbar was removed a few years ago so that it wouldn't clog the floodway, and I haven't seen the latter species in the park since.

After crossing the footbridge, I head west, all the while scanning the trees in the back yards to my left. My next stop is the bay 150 metres to the north (map location 3 ). This bay and the one just to the east were dredged out in 1988 . Willets, American Avocets, and the occasional Solitary Sandpiper can be seen along the shore in spring; these give way to Spotted Sandpipers and Greater Yellowlegs in summer, and Common Snipe and Green-winged Teal in the fall. In spring the bay is also one of the best places to see Ringnecked Ducks (rare), Bufflehead,
Canvasback, Lesser Scaup, and the other diving ducks. In August and September, large mixed flotillas of Mallards, Northern Shovelers, Gadwall, and Blue-winged Teal - some numbering more than 200 individuals - gather in the bay prior to fall migration. I always examine these flocks carefully for rarer species such as Wood Duck, which have appeared here three times over the past five years.

The grassy area to the south and west of the creek is studded with elm and ash trees in which Eastern Kingbirds have occasionally nested. Western Kingbirds generally perch in the trees closer to the McCarthy Street bridge. Following the path as it twists south and then west, I scan the treed area in the hope of seeing (during May, at least), a Rose-breasted Grosbeak or a repeat of the Blue-headed Vireo and the female Eastern Bluebird that appeared here on 18 May 1997. Perhaps the latter bird was the same one that visited my back yard for five days thereafter. I also give the denser brush along the creek a good looking

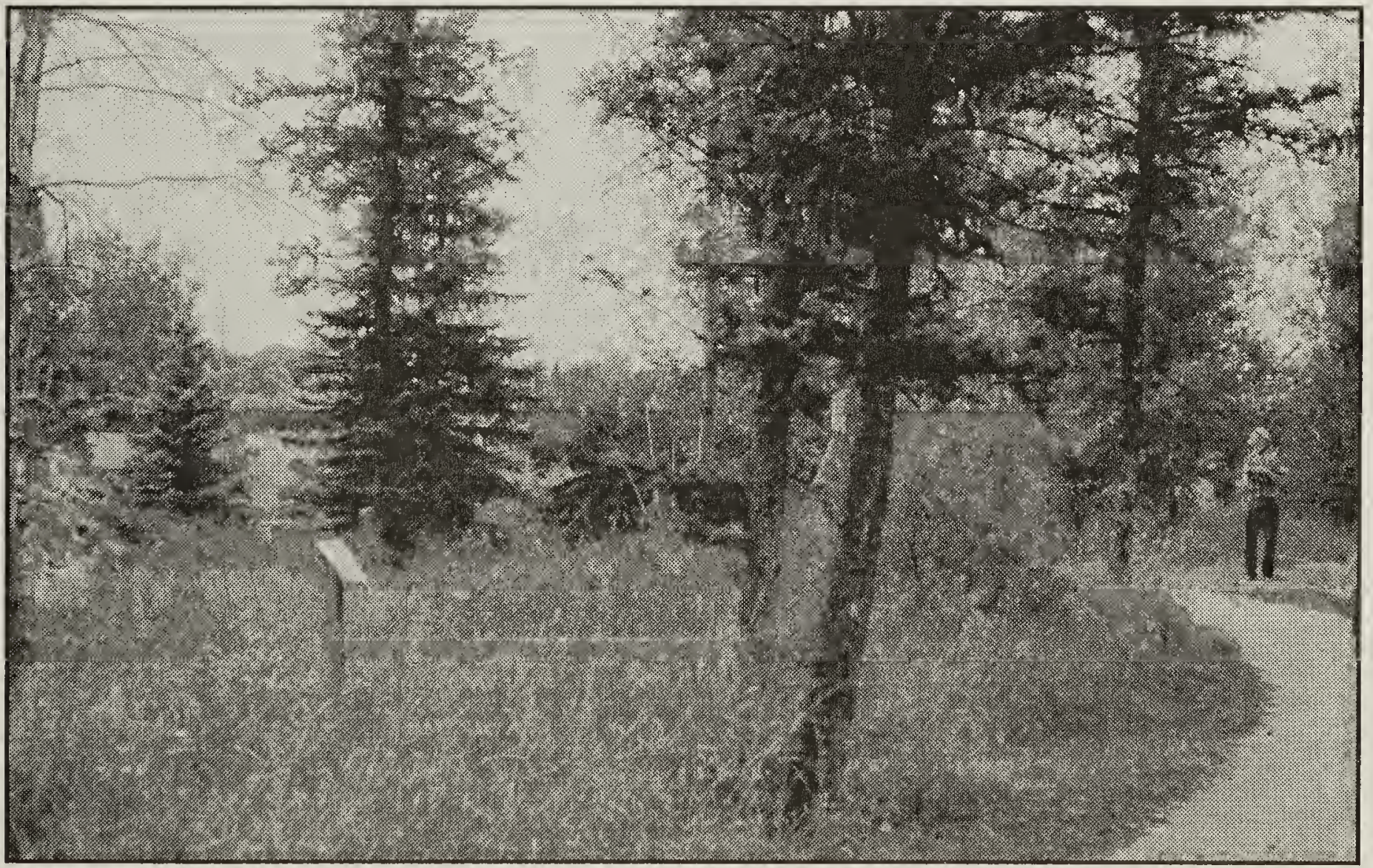


over, because it often holds warblers, sparrows, vireos, and kingbirds.

Heading west under the McCarthy Street bridge, I make for the thickets of Red-osier Dogwood, buffaloberry, willow, and lilac on the far side (map location 4). These bushes attract such passerines as the Magnolia Warbler I saw on the May 1998 bird count and, in September and October, Orange-crowned Warblers and a variety of sparrows. These species tend to respond well to pishing, as did the Winter Wren I flushed on 30 September 2000. This spot is also a favorite haunt of the skulkier species, such as Brown Thrasher.

About 100 metres beyond a bridge over a small drainage ditch that marks the end of the dense cover, a sign at a crossroads announces that the pathway through A. E. Wilson Park forms part of the Trans-Canada Trail. To the right of the sign lies the footbridge to Prairie Island (map location 5). Before crossing the bridge, I usually take a good look at the flocks of ducks that dabble in the channel between the island and the south shore of the creek because, well, you never know when a Garganey might turn up. The low bushes on the far side of the bridge often shelter sparrows, and the nearby dead cottonwood is a favorite perch for everything from warblers to magpies. The expanse of water to the north is the widest and deepest stretch of creek in the park and a favorite haunt of diving ducks and grebes. I observed a Rednecked Grebe here among a flock of Horned Grebes in April 1998, and I'm eager to see whether a Clark's Grebe might put in an appearance one of these springs.

A footbridge at the west end of Prairie Island (map location 6), leads to the most productive location in the entire park - Boreal Island (map location 7and Fig. 4). The diversity and relative density of the vegetation on the island attract such breeding species as Yellow Warbler, Baltimore Oriole, Song Sparrow, Mourning Dove, Cedar Waxwing, and Warbling Vireo. This feature also makes it a hangout for migrating warblers and sparrows.

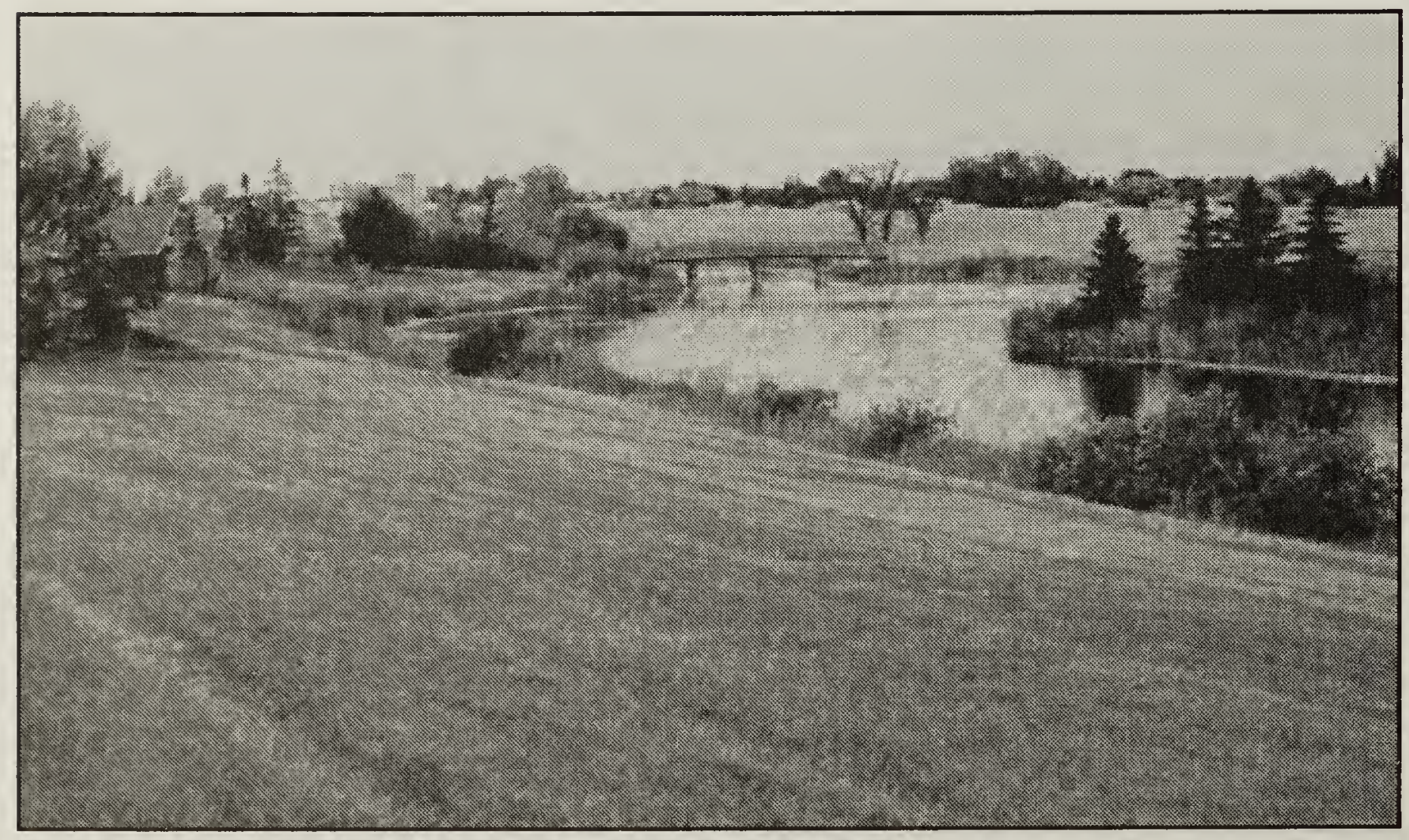

Figure 5. Looking north to the footbridge. The tip of Sparrow Finger is on the right and Prospect Corner is in the upper left.

Eric Greenway 
"Sparrow Finger", which is what I call the narrower northwestern end (map location 8), is especially good for sparrows. Among the more uncommon warblers that have shown up on the island are: Chestnut-sided, Cape May, Connecticut, and Nashville; among the more uncommon sparrows: Swamp, LeConte's, Fox, and Golden-crowned. The latter bird, observed on Sparrow Finger on 26 and 27 April 1998, turned out to be the sixth recorded sighting for Regina, and the twenty-third for Saskatchewan. Other birds of note that have turned up here are Ruby-throated Hummingbird, Alder Flycatcher, Eastern Phoebe, Northern Shrike, Blue Jay, Purple Finch, and White-winged Crossbill. In fall, Merlins sometimes zoom low just above the gravel path that encircles Sparrow Finger so as to surprise Greater Yellowlegs feeding along the shore.

The gravel path across Boreal Island divides just after it leaves the bridge from Prairie Island: one half swings northeast through the low willows and spruces along the creekside, while the other cuts through the taller trees and denser brush of the center of the island. In the early morning it's best to take the creekside route, so that you can have the sun at your back as you scan the brush and trees to the west. l'll often bird this path as far as the center of the island and then double back and bird along the interior trail before taking a couple of turns around Sparrow Finger.

Boreal Island tends to blow hot or cold however, and when it's blowing cold I head for the strip of low trees and bushes across the creek to the southwest (map location 9). Warblers often forage here, and once I even saw a Blue-headed Vireo, but my most memorable experience in this location was seeing eight Brown Thrashers emerge one by one from a thicket alongside the chainlink fence at the edge of the park.

After crossing the bridge from Boreal Island to the mainland, I take a right turn, stopping at the promising patch of conifers opposite Sparrow Finger. It

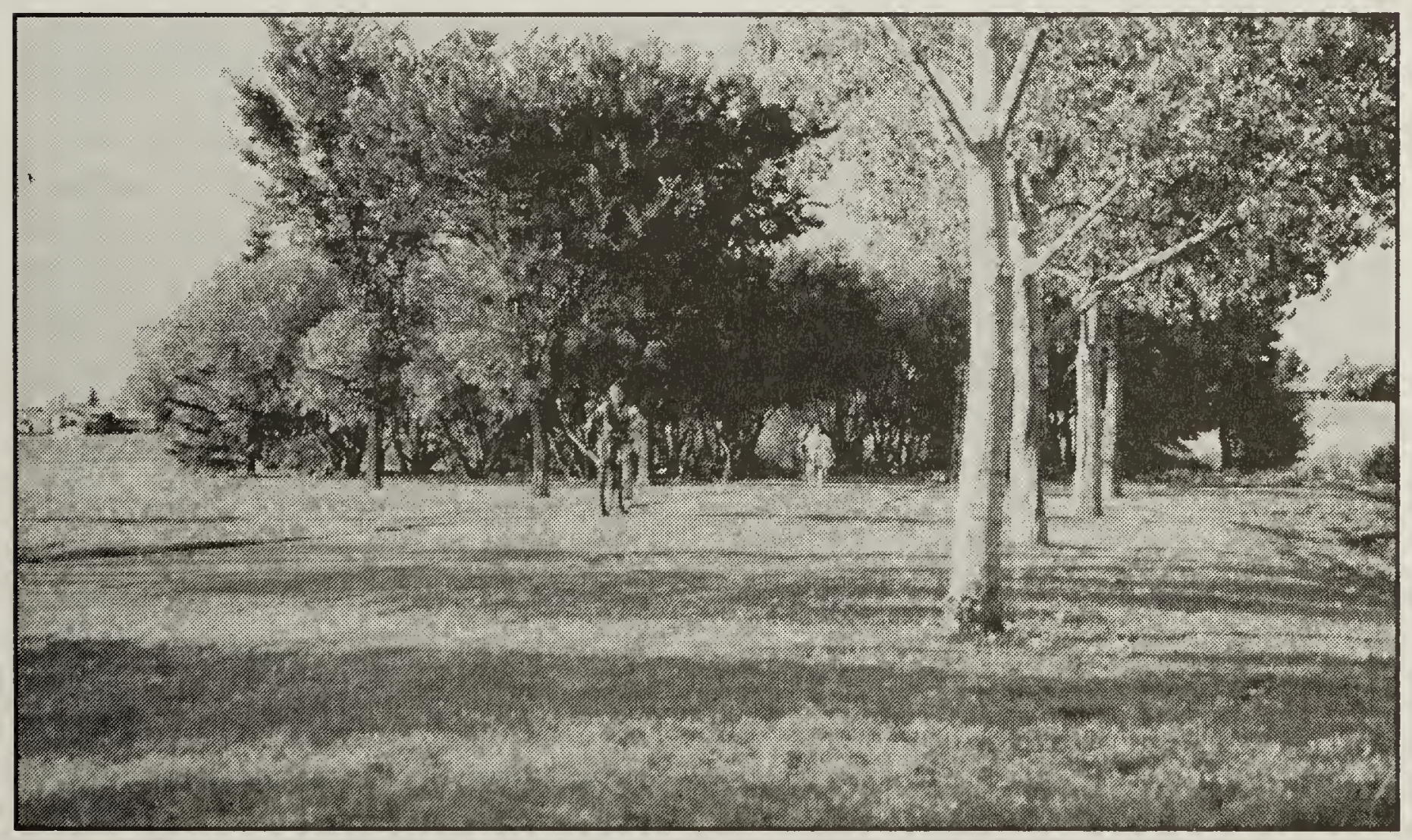

Figure 6. Looking north into The Bower. 
has produced Chestnut-sided Warblers, but normally holds very little in the way of avian life apart from Chipping Sparrows and House Finches. This is, however, the highest spot in the park (map location 10) - I call it "Prospect Corner" - and thus an ideal vantage point from which to scan the northern and western horizons and the sky overhead. Since many birds in transit seem to follow the creek, you never know what might show up: Broadwinged and Cooper's Hawks, Great Blue Heron, and Sandhill Crane are all possibilities at the right time of year.

After another 50 metres or so the path divides; one route leads west and another east across a footbridge (map location 11 and Fig. 5). I normally don't cross this bridge unless I notice a raptor on the three tall trees across the creek to the north. A large group of Burrowing Owls once bred in the hilly area just to the east of the trees according to a longtime (human) resident of the area.

About 20 metres west of the intersection lies one of the most delightful sections of the park, a bower of willows that forms an arch over the path (map location 12 and Fig. 6). I observed a Philadelphia Vireo here during the May 1999 bird count, and the willows also shelter warblers, Western Kingbirds, Baltimore Orioles, migrant thrushes, and the occasional Spotted Towhee. The sandy beach that comes into view on the far side of the bower often holds ducks, gulls, and shorebirds, and the occasional surprise, like the lone Snow Goose that once showed up in a flock of Canada Geese. I use the conifers bordering the creek as a blind because the waterfowl and shorebirds in this neck of the park tend to spook easily. And since the creek is quite wide and deep at this spot it attracts diving ducks during migration. Wilson's Phalarope and Surf Scoter have turned up here, and the far shore has produced Common Snipe and other shorebirds.

The path then snakes its way to Ritter Avenue, at the park's northern limit. Western Meadowlarks and kingbirds often perch in the widely-scattered trees in the field to the south. If Common Grackles are feeding in the grass just to the east of the power line, I always scrutinize the flock for the more dainty Brewer's Blackbirds. The bridge itself (map location 13) and the nearby power lines serve as perches for migrating Belted Kingfishers, and the weir just to the east is a favorite feeding-place of Willet, Greater Yellowlegs, and Spotted Sandpiper.

To the west and south of the bridge is a grassy field that I call "LeConte's Field" (map location 14), because of the LeConte's Sparrows that usually reside here from late May until midSeptember. Towards mid-summer they are joined by Sedge Wrens, which are at times surprisingly tame. A very vocal group of three once made its way through the two-metre-high grass to within a metre of me. Bobolinks often show up during spring migration and have occasionally stayed for the summer. All three species are probable breeders. Common Yellowthroats, Song Sparrows, and Clay-colored Sparrows also inhabit, and likely breed in, the grasses and creekside reeds.

Leconte's Field is also one of the best places in the park to see raptors, which sometimes perch on fence posts or in the belt of trees to the west that shields the Paul Dojack Centre from view. Northern Harrier, Red-tailed, Swainson's, and Cooper's hawks, American Kestrel, Merlin, and Shorteared Owl all frequent the area. Also of note was a Nelson's Sharp-tailed Sparrow that appeared one September. 
Swallows feed overhead, and the monotonous two-note call of the Purple Martin can invariably be heard from May through August. The martins share a martin house just to the south with House Sparrows.

Having reached the top end of my circuit at this point, I head back over the field, staying close to the houses in Dieppe Place, to look for birds I didn't see on the way up. I then revisit Boreal Island and, if pressed for time, make my way to the McCarthy Street bridge and head home along the north bank of the creek. I usually bird only the south bank because it has more trees and better habitat overall. However, the north bank has yielded a few uncommon to rare birds such as Mountain Bluebird, Loggerhead Shrike, Say's Phoebe, and, on 12 August 1997, one very disoriented Upland Sandpiper.

During the dog days of summer the number (usually around 40) and variety of species seen on each visit remain fairly constant, but there are always new avian experiences to be had: a mock attack by a Purple Martin when I strayed too near its house; an Eastern Kingbird whacking a dragonfly against a tree (presumably to ensure its demise and to soften it up) before feeding it to its young; and a Great Horned Owl roosting in dense foliage, its presence betrayed by shrieking Robins.

By contrast, spring migration regularly brings a rich fallout of diverse and unexpected species. May 19, 2000, is a case in point, providing not only abundance (57 species, a personal best single day total) but two rarities: a first-year male Chestnut-sided Warbler on Boreal Island and a Hooded Merganser on the creek to the east.

A. E. Wilson Park's checklist of 169 species includes 19 species of sparrow and 18 species of warbler, and compares favorably with those of three parks in Saskatoon that receive mention in the latest edition of $A$ BirdFinding Guide to Canada. ${ }^{1}$ During spring, summer, and fall it also rivals Regina's Wascana Park, as far as the number of observable species is concerned. In 1997 the park was added to the sites to be covered in the city's May bird count, but visits by serious birdwatchers continue to be as rare as Northern Shrikes or Blue Jays. Perhaps, as its trees mature, it will come to play Medina to Wascana Park's Mecca in the minds of local birders.

\section{Acknowledgements}

I would like to acknowledge the assistance of Eric Greenway, Trevor Herriot, and Diane Ayer, each of whom proofread the manuscript and offered editorial suggestions. Eric also took the photographs used in the article. Longtime Dieppe Place resident Ed Lamb filled me in on the history of the development of the park and contributed the sighting record for Burrowing Owl. Lloyd Isaak, Coordinator of Landscape Design and Capital Planning with the City of Regina, contributed information on the city of Regina's master plan for the park. Other background information on the park was provided by Ivan J. Saunders, City of Regina Archivist; Janine Daradich, City of Regina Community Services, and the staff of the Regina Public Library's Prairie History Room.

1. Finlay, J. Cam, Ed. 2000. A Birdfinding Guide to Canada. McClelland and Stewart, Toronto

2. Realistic Environment Recreated. Regina Leader-Post, 8 June 1987.

3. Smith, Alan R., 1996. Atlas of Saskatchewan Birds. Saskatchewan Natural History Society, Regina. p.8. 